\title{
OfFice PAPERs STABILITY DURING ACCELERATED Ageing
}

\section{Plazonic, I.; BARBARIC-MikoceVic, Z. \& DZIMBeG-Malcic, V.}

Abstract: In this work the influence of different surfactants and their mass fractions on the optical characteristics of office papers, made from recycled fibres and mixed sources, was examined. Sodium lauryl ether sulfate, cocamidopropyl betaine and fatty alcohol etoksylate like surface active agent were used. The reflective spectra of treated papers were measured before and after accelerated ageing. The results have shown that fibres origin and amount of fillers in paper structure have the most important influence on reflectance spectra. Accelerated ageing has the most significant influence on virgin fibres, while this influence is decreased in office papers. Surface active agent molecules adsorbed on virgin fibres stabilise filter paper during electromagnetic radiation while this stabilisation is significantly reduced for office paper with more complex structure. Chemical composition of paper fillers and surface active agents has important influence on stabilisation possibility of office paper during accelerated ageing.

Key words: surfactant, office paper, reflectance, accelerated ageing
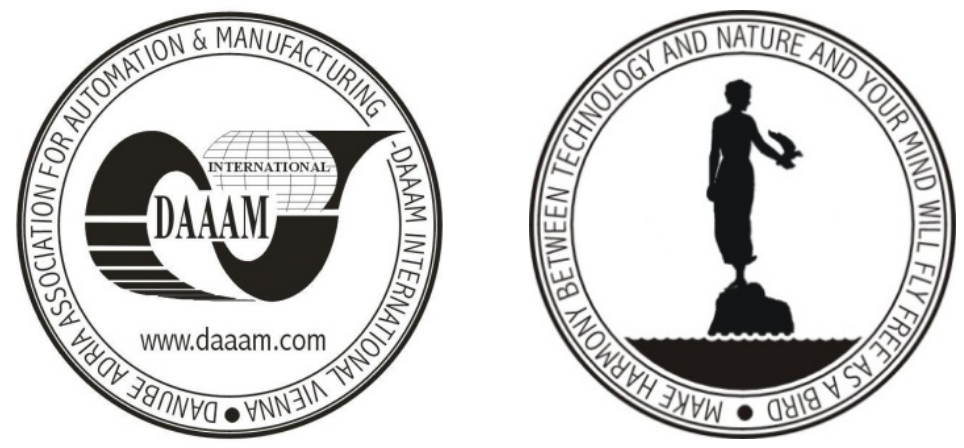

Authors' data: B. Sc. Plazonic, I[vana]; Dr.Sc. Barbaric-Mikocevic, Z[eljka]; Dr. Sc. Dzimbeg-Malcic, V[esna], Faculty of Graphic Arts, University of Zagreb, Getaldiceva 2, 10000 Zagreb, Croatia, ivana.plazonic@grf.hr, barbaric@grf.hr, vesna.dzimbeg.malcic@grf.hr

This Publication has to be referred as: Plazonic, I[vana]; Barbaric-Mikocevic, Z[eljka] \& Dzimbeg-Malcic, V[esna] (2009). Office Papers Stability During Accelerated Ageing, Chapter 35 in DAAAM International Scientific Book 2009, pp. 333-340, B. Katalinic (Ed.), Published by DAAAM International, ISBN 978-3901509-69-8, ISSN 1726-9687, Vienna, Austria

DOI: $10.2507 /$ daaam.scibook.2009.35 